\title{
Penggunaan Metode Mind Mapping untuk Meningkatkan Kompetensi Menulis Karangan Siswa Kelas XII SMK Negeri 2 Garut
}

\author{
Empong Saodah \\ SMK Negeri 2 Garut, Jawa Barat, Indonesia \\ epongsaodah@gmailcom
}

\begin{abstract}
Researchers tried to use the mind mapping method to overcome some of the problems that occurred. The researcher tried this method because the researcher had attended training and read a book on Quantum Teaching and Learning by Bobbry D'botter at a private high school in Cibinong, Bogor Regency. In the training and the book, the material for the mind mapping method was very interesting. The research method used is quantitative and qualitative methods. Quantitative methods are used to determine how much student learning outcomes or achievement after using this mind mapping method. And qualitative methods are used to find out how the results of students' interest tests in Indonesian subjects through filling out questionnaires, before and after the implementation of the mind mapping method in this class. There are students who like the mind mapping method, some are just ordinary. Most students said it was easier to write an essay by making a mind map first. No one said it was getting dizzy anymore. What's interesting about mind mapping is the image, color and manufacture. Group study is preferred. With more intensive monitoring, all students are willing to work. The mind mapping method is very necessary in learning Indonesian, especially in the competence of writing essays. By making an outline in the form of a mind map that can be drawn and colored at will, it can motivate students to express their ideas through various images and colors. Mind mapping can also generate ideas, making it easier for students to write essays.
\end{abstract}

\section{Keywords: Mind Mapping, Competence, Writing Essay, Students}

\begin{abstract}
ABSTRAK
Peneliti mencoba menggunakan metode mind mapping untuk mengatasi sebagian dari permasalahan-permasalahan yang terjadi. Peneliti mencoba metode ini karena peneliti pernah mengikuti pelatihan dan membaca buku tentang Quantum Teaching and Learning karya Bobbry D'botter di salah satu SMA Swasta di Cibinong Kabupaten Bogor. Dalam pelatihan dan buku itu materi metode mind mapping yang peneliti anggap sangat menarik. Metode penelitian yang digunakan adalah metode kuantitatif dan kualitatif. Metode kuantitatif digunakan untuk mengetahui seberapa hasil belajar atau prestasi belajar siswa setelah menggunakan metode mind mapping ini. Dan metode kualitatif digunakan untuk mengetahui bagaimana hasil tes minat siswa terhadap mata pelajaran Bahasa Indonesia melalui pengisian angket, sebelum dan sesudah diimplementasikannya metode mind mapping di kelas ini. Ada siswa yang suka dengan metode mind mapping, ada pula yang biasa saja. Kebanyakan siswa mengatakan lebih mudah menulis karangan dengan membuat mind mappingnya terlebih dahulu. Sudah tidak ada yang mengatakan tambah pusing. Yang menarik dari mind mapping adalah gambar, warna dan pembuatannya. Belajar kelompok lebih disukai. Dengan pemantauan yang lebih intensif, semua siswa sudah mau bekerja. Metode mind mapping
\end{abstract}




\section{Edulnovasi: Journal of Basic Educational Studies Volume 2 Nomor 1 (2022) 73-84 P-ISSN 2774-5058 E-ISSN 2775-7269 DOI: 47467/eduinovasi.v2.i1.669}

sangat diperlukan dalam pembelajaran Bahasa Indonesia khususnya pada kompetensi menulis karangan mengarang. Dengan membuat kerangka karangan dalam bentuk mind mapping yang dapat digambari dan diwarnai sesuka hati, dapat memotivasi siswa untuk mengekspresikan gagasannya melalui gambar yang beraneka ragam dan warna. Mind mapping juga dapat memunculkan ide, sehingga mempermudah siswa dalam menulis karangan/mengarang.

Kata kunci: Mind Mapping, Kompetensi, Menulis Karangan, Siswa

\section{PENDAHULUAN}

Pembelajaran bahasa Indonesia secara fungsional adalah pembelajaran yang lebih menekankan siswa untuk belajar berbahasa sebagai alat berkomunikasi. Untuk itu, pendekatan pembelajaran yang sesuai adalah pendekatan komunikatif. Pembelajaran bahasa Indonesia dengan pendekatan komunikatif diarahkan untuk membentuk kompetensi komunikatif, yakni kompetensi kemampuan untuk menggunakan bahasa Indonesia sebagai alat komunikasi, baik pada aspek pemahaman, aspek penggunaan, maupun aspek apresiasi (Suparno 2001).

Melalui pembelajaran bahasa Indonesia diharapkan siswa memiliki kemampuan untuk menangkap makna dari sebuah pesan atau informasi yang disampaikan serta memiliki kemampuan untuk menalar dan mengemukakan kembali pesan atau informasi yang diterimanya itu baik secara lisan maupun tulisan. Dalam pembelajaran Bahasa Indonesia, siswa juga diharapkan memiliki kemampuan untuk mengekpresikan berbagai pikiran, gagasan, pendapat, dan perasaan dengan menggunakan bahasa yang baik dan benar melalui lisan dan tulisan. Kompetensi komunikatif itu dapat dicapai melalui proses pemahiran yang dilatihkan dan dialami oleh siswa dalam kegiatan pembelajaran.

Salah satu aspek keterampilan berbahasa yang berkaitan dengan pengungkapan pikiran, gagasan, pendapat, dan perasaan tersebut adalah keterampilan menulis karangan karangan. Keterampilan menulis karangan karangan sebagai keterampilan berbahasa bersifat produktif-aktif merupakan salah satu kompetensi dasar berbahasa yang harus dimiliki siswa agar terampil berkomunikasi secara tertulis.

Berdasarkan pengalaman dan pengamatan di kelas, ditemukan bahwa menulis karangan kerap kali menjadi suatu hal yang kurang diminati dan kurang mendapat respon yang baik dari siswa. Siswa tampak mengalami kesulitan ketika harus menulis karangan karangan. Siswa tidak tahu apa yang harus dilakukan ketika pembelajaran menulis karangan dimulai. Mereka terkadang sulit sekali menemukan kalimat pertama untuk memulai sebuah tulisan. Siswa kerap menghadapi sindrom kertas kosong (blank page syndrome) tidak tahu apa yang akan ditulisnya. Mereka takut salah, takut berbeda dengan apa yang diinstruksikan gurunya.

Keterampilan menulis karangan di kelas terkadang juga hanya diajarkan pada saat pembelajaran menulis karangan saja, pahadal pembelajan keterampilan menulis 


\section{Edulnovasi: Journal of Basic Educational Studies Volume 2 Nomor 1 (2022) 73-84 P-ISSN 2774-5058 E-ISSN 2775-7269 DOI: 47467/eduinovasi.v2.i1.669}

karangan dapat dipadukan atau diintegrasikan dalam setiap proses pembelajaran di kelas. Pengintegrasian itu dapat bersifat internal dan eksternal. Pengintegrasian internal berati pembelajaran menulis karangan diintegrasikan dalam pembelajaran keterampilan bebahasa yang lain. Menulis karangan dapat pula diintegrasikan secara eksternal dengan mata pelajaran lain diluar mata pelajaran bahasa Indonesia.

Pembelajaran menulis karangan juga sering membingungkan siswa karena pemilahan yang kaku dalam mengajarkan jenis-jenis tulisan atau jenis-jenis paragraf, seperti narasi, eksposisi, deskripsi, dan argumentasi. Pengategorian yang kaku itu membuat siswa menulis karangan terlalu berhati-hati karena takut salah, tidak sesuai dengan jenis karangan yang dituntut. Padahal, ketakutan untuk berbuat salah tersebut dapat mematikan kreativitas siswa untuk menulis karangan. Selain itu, Halliday (dalam Tompkins \& Hoskisson, 1991:187) menyatakan bahwa pengategorian jenis-jenis karangan tersebut terlihat artifasial ketika kita meminta siswa menggunakannya untuk berbagai tujuan yang berbeda, sebab siswa terkadang mengombinasikan dua atau lebih kategori untuk mengemukakan sebuah gagasan dalam tulisannya. Menulis karangan merupakan suatu keterampilan dan keterampilan itu hanya akan berkembang jika dilatihkan secara terus menerus atau lebih sering. Memberikan kesempatan lebih banyak bagi siswa untuk berlatih menulis dalam berbagai tujuan merupakan sebuah cara yang dapat diterapkan agar keterampilan menulis meningkat dan berkembang secara cepat.

Berdasarkan permasalahan-permasalahan tersebut di atas, peneliti mencoba menggunakan metode mind mapping untuk mengatasi sebagian dari permasalahanpermasalahan itu. Peneliti mencoba metode ini karena peneliti pernah mengikuti pelatihan dan membaca buku tentang Quantum Teaching and Learning karya Bobbry $D^{\prime} b o t t e r$ di salah satu SMA Swasta di Cibinong Kabupaten Bogor. Dalam pelatihan dan buku itu materi metode mind mapping yang peneliti anggap sangat menarik. Berdasarkan pemahaman peneliti, dari materi metode mind mapping yang disampaikan oleh Ir. Asep Durrahman (Alm), metode ini dapat memunculkan ide dan gagasan yang menarik dan tak terbatas, karena ada rangsangan berupa gambargambar sesuai dengan ide yang muncul serta dapat diberi warna-warna yang indah dan juga menarik. Dengan metode ini diharapkan para siswa menjadi lebih tertarik untuk mengikuti mata pelajaran Bahasa Indonesia materi menulis karangan.

Menurut arti katanya, mind mapping dapat diartikan sebagai "pemetaan pikiran". Untuk memetakan pikiran, kita perlu melibatkan imajinasi, asosiasi, pengulangan dan visualisasi. Kemudian kita buat catatan-catatan yang divisualisasikan dalam bentuk password. Metode mind mapping adalah metode meringkas yang menggunakan segala macam metode untuk memudahkan mengingat, tapi hanya password-password saja yang diletakkan pada mind mapping. (Diklat Peningkatan Mutu dan Profesionalisme Guru, 2006, Neuroscience Super Teaching: 55). Menurut Mbak Atik, mind mapping dapat memunculkan ide, dapat mengembangkan ide dan menarik, karena dapat diberi gambar-gambar yang menarik sesuai dengan ide yang muncul serta dapat diberi warna yang menarik pula. (Mbak Atik adalah pemateri "Metode Pembelajaran" pada diklat inovasi pembelajaran guru mata pelajaran Bahasa Inggris SMP DIY, tanggal 10 Pebruari s/d 15 Mei 2006). 


\section{Edulnovasi: Journal of Basic Educational Studies Volume 2 Nomor 1 (2022) 73-84 P-ISSN 2774-5058 E-ISSN 2775-7269 DOI: 47467/eduinovasi.v2.i1.669}

Bagi siswa yang suka menggambar, dapat mengekspresikan gagasannya melalui gambar yang beraneka ragam dan berbagai warna indah dalam mind mappingnya. Jika siswa sudah merasa tertarik dan merasa nyaman dalam mengerjakan tugasnya, guru akan lebih mudah dalam menyampaikan materi, sehingga siswa tidak lagi merasa kesulitan dan tertekan dalam mengikuti pelajaran Bahasa Indonesia khususnya pada kompetensi atau materi menulis karangan. Menulis karangan merupakan suatu proses kreatif yang banyak melibatkan cara berpikir divergen (menyebar) daripada konvergen (memusat) (Supriadi, 1997). Menulis karangan tidak ubahnya dengan melukis. Penulis memiliki banyak gagasan dalam menulis karangankannya. Kendatipun secara teknis ada kriteria-kriteria yang dapat diikutinya, tetapi wujud yang akan dihasilkan itu sangat bergantung pada kepiawaian penulis dalam mengungkapkan gagasan. Banyak orang mempunyai ide-ide bagus di benaknya sebagai hasil dari pengamatan, penelitian, diskusi, atau membaca. Akan tetapi, begitu ide tersebut dilaporkan secara tertulis, laporan itu terasa amat kering, kurang menggigit, dan membosankan. Fokus tulisannya tidak jelas, gaya bahasa yang digunakan monoton, pilihan katanya (diksi) kurang tepat dan tidak mengena sasaran, serta variasi kata dan kalimatnya kering.

Sebagai proses kreatif yang berlangsung secara kognitif, penyusunan sebuah tulisan memuat empat tahap, yaitu: (1) tahap persiapan (prapenulisan), (2) tahap inkubasi, (3) tahap iluminasi, dan (4) tahap verifikasi/evaluasi. Keempat proses ini tidak selalu disadari oleh para pembelajar bahasa Indonesia sebagai bahasa asing. Namun, jika dilacak lebih jauh lagi, hampir semua proses menulis karangan (esai, opini/artikel, karya ilmiah, artistik, atau bahkan masalah politik sekali pun) melalui keempat tahap ini. Harap diingat, bahwa proses kreatif tidak identik dengan proses atau langkah-langkah mengembangkan laporan tetapi lebih banyak merupakan proses kognitif atau bernalar.

\section{METODE PENELITIAN}

Penelitian tindakan kelas ini dilaksanakan di SMK Negeri 2 Garut, kelas XII Teknik Audio Video Waktu pelaksanaan, pada semester 2 tahun pelajaran 2019/2020, tepatnya penelitian ini dimulai pada pertengahan bulan Januari sampai dengan awal Maret 2019. Sebagai subyek penelitian, yaitu para siswa yang peneliti ambil sebagai sampel penelitian, adalah siswa kelas XII Teknik Audio Video SMK Negeri 2 Garut. Pengambilan sampel ini adalah secara acak, jadi sembarang kelas XII yang peneliti ajar. Karakteristik kelas XII Teknik Audio Video ini adalah siswa yang sejak mendaftar telah memilih jurusan. Komposisi keseimbangan jumlah siswa laki-laki dan siswa perempuan yang diterima di SMK Negeri 2 Garut, dibagi menjadi 12 kelas. Jumlah siswa di kelas XII Teknik AudioVideo ini ada 36 siswa, dengan komposisi 36 putra. Nomor siswa diurutkan berdasarkan abjad, tanpa memandang jenis kelamin.

Metode penelitian yang digunakan adalah metode kuantitatif dan kualitatif. Metode kuantitatif digunakan untuk mengetahui seberapa hasil belajar atau prestasi belajar siswa setelah menggunakan metode mind mapping ini. Dan metode kualitatif digunakan untuk mengetahui bagaimana hasil tes minat siswa terhadap 


\section{Edulnovasi: Journal of Basic Educational Studies Volume 2 Nomor 1 (2022) 73-84 P-ISSN 2774-5058 E-ISSN 2775-7269 DOI: 47467/eduinovasi.v2.i1.669}

mata pelajaran Bahasa Indonesia melalui pengisian angket, sebelum dan sesudah diimplementasikannya metode mind mapping di kelas ini. Dalam penelitian ini, prosedur penelitianya menggunakan prosedur penelitian model Kemmis dan Mc Taggart (1982 : 11). Setiap tahap atau siklus terdiri dari perencanaan, tindakan, observasi dan refleksi.

Berdasarkan tujuan penelitian yang pertama yaitu meningkatkan minat belajar Bahasa Indonesia siswa, apabila ada peningkatan minat berdasarkan hasil angket sebelum dan sesudah penelitian dilakukan, maka tindakan dianggap berhasil. Berdasarkan tujuan kedua, meningkatkan kompetensi dan prestasi mengarang siswa, apabila ada peningkatan hasil atau prestasi atau nilai berdasarkan hasil pretes dan postes penelitian yang dilaksanakan. Atau menurut St Singgih (1998) apabila 85\% siswa berhasil mencapai nilai KKM (75), pada waktu postes materi penelitian, maka tindakan dianggap berhasil (Singgih St, 1998 : ...). Dan untuk tujuan ketiga, mengetahui bagaimana respon siswa terhadap implementasi metode mind mapping dalam pembelajaran aspek writing, apabila berdasarkan pengamatan oleh kolaborator dan peneliti, siswa nampak suka dengan metode mind mapping ini, siswa tidak lagi menghindari pembelajaran dengan berbagai alasan seperti dikemukakan dalam latar belakang masalah, serta refleksi dengan siswa, menunjukkan respon yang positif, maka tindakan dianggap berhasil.

\section{HASIL DAN PEMBAHASAN}

\section{Siklus I}

Pada siklus pertama, proses pembelajaran direncanakan dilaksanakan dalam empat kali pertemuan seperti dalam jadwal kegiatan penelitian berikut :

\begin{tabular}{|c|c|c|c|c|}
\hline No & Tanggal & Juml jam & Kegiatan Pembelajaran & Keterangan \\
\hline 1 & $7-01-19$ & 2 & Pengisian agket dan pretes & Klasikal \\
\hline 2 & $10-01-19$ & 2 & $\begin{array}{lr}\begin{array}{l}\text { Pengenalan metode } \\
\text { mapping }\end{array} & \text { mind } \\
\text { implan }\end{array}$ & Klasikal \\
\hline 3 & 14-01-19 & 2 & $\begin{array}{l}\text { Mempelajari pola kalimat } \\
\text { dalam mengarang : dan } \\
\text { latihhan membuat kalimatnya } \\
\text { dikaitkan dengan tema } \\
\text { "Harapanku". }\end{array}$ & $\begin{array}{ll}\text { Klasikal } & \text { dan } \\
\text { berpasangan } & \end{array}$ \\
\hline 4 & 17-01-19 & 2 & $\begin{array}{l}\text { Pembentukan kelompok } \\
\text { untuk mengerjakan latihan } \\
\text { soal yang mendukung materi } \\
\text { mengarang. }\end{array}$ & Tugas kelompok \\
\hline
\end{tabular}


Edulnovasi: Journal of Basic Educational Studies

Volume 2 Nomor 1 (2022) 73-84 P-ISSN 2774-5058 E-ISSN 2775-7269

DOI: 47467/eduinovasi.v2.i1.669

\begin{tabular}{|l|l|l|l|l|}
\hline 5 & $21-01-19$ & 2 & $\begin{array}{l}\text { Membuat mind mapping } \\
\text { untuk menulis karangan } \\
\text { deskripsi dilanjutkan } \\
\text { penulisan deskripsinya. }\end{array}$ & Tugas kelompok \\
\hline 6 & $28-01-19$ & 2 & $\begin{array}{l}\text { Membahas tugas kelompok } \\
\text { dan mengerjakan tugas } \\
\text { berikutnya. }\end{array}$ & Klasikal dan tugas kel. \\
\hline 7 & $04-02-19$ & 2 & $\begin{array}{l}\text { Ulangan Harian mengarang } \\
\text { dengan metode mind } \\
\text { mapping. Ulangan individu }\end{array}$ & $\begin{array}{l}\text { Refleksi dengan siswa dan } \\
\text { persiapan kegiatan siklus } \\
\text { kedua }\end{array}$ \\
\hline 8 & $07-02-19$ & 2 & Klasikal & \\
\hline
\end{tabular}

Semua kegiatan dapat dilaksanakan sesuai dengan rencana tersebut di atas.

Observasi dilakukan oleh kolaborator Lilis Sri Mulyani, S.Pd. dan peneliti sendiri berdasarkan Lembar Pengamatan yang telah disiapkan. Adapun hasilnya adalah sebagai berikut :

\section{Hasil Pengamatan siklus Pertama :}

1) Waktu pengamatan : Pertemuan 1 - 7 (7 Januari s/d 4 Pebruari 2019).

2) Tempat pelaksanaan : Ruang kelas XII SMK Negeri 2 Garut.

3) Catatan Pelaksanaan :

a. Siswa :

- Secara umum seluruh siswa mengikuti pelajaran dengan baik dan tertib.

- Sebagian besar siswa nampak tertarik dengan metode, materi dan cara penyampaian materi yang lain dari biasanya. Siswa selalu dilibatkan.

- Siswa nampak lebih senang belajar dalam kelompok.

\section{b. Guru (Peneliti) :}

- Sudah melaksanakan pembelajaran sesuai dengan RPP.

- Selalu berusaha menarik minat siswa dengan cara melibatkan banyak siswa dalam menjelaskan materi.

- Sudah bagus dalam membentuk kelompok belajar, sudah adil.

- Sudah berusaha memunculkan kretifitas siswa dengan membebaskan siswa dalam memberi nama kelompok, memilih kertas dan ukurannya, serta pewarnaan dalam pembuatan mind mapping.

\section{c. Sarana dan Prasarana Sekolah :}

- Untuk penerangan, cukup, sehingga pembelajaran di kelas lancar.

- Semua kebutuhan alat tulis lengkap. 


\section{Edulnovasi: Journal of Basic Educational Studies \\ Volume 2 Nomor 1 (2022) 73-84 P-ISSN 2774-5058 E-ISSN 2775-7269 \\ DOI: 47467/eduinovasi.v2.i1.669}

\section{d. Kejadian-kejadian :}

- Pada pertemuan keempat, ada 1 kelompok siswa laki-laki yang ramai, ternyata mereka belum dapat menentukan nama kelompoknya, karena keempat anggotanya menginginkan nama usulannya dipakai. Akhirnya guru menengahi dengan memanggil seorang siswa untuk mengundi nama-nama yang diusulkan. Peristiwa ini menarik perhatian semua siswa dan guru di kelas itu.

- Pada pertemuan keempat pula, ada instruksi yang lupa disampaikan, sehingga disampaikan pada waktu siswa sedang asyik mengerjakan tugas kelompok, menurut kolaborator hal ini mengganggu konsentrasi siswa.

\section{e. Penilaian Proses :}

- Secara keseluruhan proses pembelajaran pada siklus 1 sudah cukup baik,

- Topiknya terlalu luas, dalam siklus 1 nampak ada 3 topik yang dipelajari yaitu "Sekolahku", "Keluargaku" dan "Kegemaranku”. Sebaiknya 1 topik saja.

- Siswa masih kurang berani bertanya dan menulis karangankan apa yang ada dalam pikiran mereka, sehingga kegiatan mengarang tampak agak lamban.

\section{f. Saran-saran :}

- Semua instruksi hendaknya disampaikan sebelum siswa mengerjakan tugas.

- Setelah memberi instruksi hendaknya dicek, apakah instruksi itu sudah dipahami oleh siswa secara keseluruhan, dengan bertanya kepada siswa.

- Untuk topic, hendaknya tidak terlalu luas, 1 Indikator cukup 1 topik saja.

Hasil refleksi dengan siswa dan kolaborator pada siklus pertama adalah :

a) Kebanyakan siswa belum kenal metode mind mapping.

b) Kebanyakan siswa menyukai metode ini walau ada yang mengangggapnya biasa saja.

c) Kebanyakan siswa mengatakan mind mapping dapat mempermudah penulisan, tapi 3 siswa mengatakan tambah pusing.

d) Yang menarik dari mind mapping adalah gambar, warna dan pembuatannya.

e) Kebanyakan siswa menyukai belajar kelompok, karena bisa bekerjasama dan tugas jadi ringan. Yang suka individu, alasannya teman-temannya tidak mau bekerja.

f) Peneliti merencanakan untuk ulangan pada siklus 2 nanti, Kertas disediakan oleh peneliti supaya sama ukurannya dan kolaborator menyetujui. 


\section{Edulnovasi: Journal of Basic Educational Studies \\ Volume 2 Nomor 1 (2022) 73-84 P-ISSN 27744-5058 E-ISSN 2775-7269 \\ DOI: 47467/eduinovasi.v2.i1.669}

\section{Siklus II}

Siklus kedua direncanakan dilaksanakan dalam 7 kali pertemuan. Langkahlangkahnya tetap sama, hanya ada penekanan tindakan seperti siswa yang mengatakan "dengan mind mapping tambah pusing" didekati dan dibimbing tersendiri. Waktu kerja kelompok lebih dipantau lagi supaya tidak ada siswa yang tidak mau bekerja lagi. Kertas ulangan disediakan oleh peneliti. Adapun jadwal kegiatannya adalah sebagai berikut :

\begin{tabular}{|l|l|l|l|l|}
\hline No & Tanggal & Juml jam & Kegiatan Pembelajaran & Keterangan \\
\hline 1. & $11-2-19$ & 2 & Pretes materi penelitian & Di kelas \\
\hline 2. & $14-2-19$ & 2 & $\begin{array}{l}\text { Mempelajari kosakata yang Penilaian Proses } \\
\text { berhubungan dengan teks } \\
\text { dan mempraktekan } \\
\text { berdasarkan instruksi, lalu } \\
\text { mengerjakan latihan }\end{array}$ \\
\hline 3. & $18-2-19$ & 2 & $\begin{array}{l}\text { Ciri karangan yang baik } \\
\text { menurut berbagai sumber } \\
\text { (PR Kelompok : mencari dari }\end{array}$ & tugas kel 4 orang \\
sumber lain)
\end{tabular}

Observasi dilakukan oleh kolaborator dan peneliti pada setiap pertemuan. Yang penting adalah mencatat kejadian-kejadian penting, penilaian proses dan saran. Hasilnya adalah :

Hasil Pengamatan siklus Kedua :

4) Waktu pengamatan : Pertemuan 1 - 7 (11 Pebruari - 07 Maret 2019).

5) Tempat pelaksanaan : Ruang Kelas XII Teknik Listrik

6) Catatan Pelaksanaan: 


\section{Edulnovasi: Journal of Basic Educational Studies \\ Volume 2 Nomor 1 (2022) 73-84 P-ISSN 2774-5058 E-ISSN 2775-7269 \\ DOI: 47467/eduinovasi.v2.i1.669}

\section{a. Siswa :}

- Siswa melaksanakan tugas dengan baik, kelas terkendali, tertib dan lancar.

- Siswa nampak menikmati pembelajaran dengan metode ini, terbukti lebih banyak siswa yang membawa pewarna lebih banyak daripada sebelumnya.

\section{b. Guru :}

- Sudah melaksanakan langkah-langkah pembelajaran dengan lebih baik.

- Dapat mengendalikan kelas, pembelajaran berjalan dengan baik dan menyenangkan.

\section{c. Sarana dan prasarana sekolah :}

- Masih seperti sebelumnya, tetapi sudah cukup.

\section{d. Kejadian-kejadian :}

- Kesenangan bagi siswa yang suka menggambar bertambah karena materi yang kedua ini memerlukan gambar-gambar untuk memperjelas teks.

- Bagi yang kurang terampil menggambar, mereka juga terlihat kreatifitasnya dengan mengguntingi gambar-gambar dari bungkus supermi, lalu ditempelkan di kertas pekerjaannya. Bagus-bagus hasilnya.

\section{e. Penilaian proses :}

- Proses pembelajaran pada siklus 2 lebih baik dan lebih sempurna dari pada siklus pertama.

\section{f. Saran :}

- Teruskan gunakan metode ini, termasuk untuk aspek atau kompetensi yang lain.

Pada akhir siklus 2 diadakan lagi refleksi dengan siswa. Hasilnya adalah :

a) Ada siswa yang suka dengan metode mind mapping, ada pula yang biasa saja.

b) Kebanyakan siswa mengatakan lebih mudah menulis karangan dengan membuat mind mappingnya terlebih dahulu. Sudah tidak ada yang mengatakan tambah pusing.

c) Yang menarik dari mind mapping adalah gambar, warna dan pembuatannya.

d) Belajar kelompok lebih disukai.

e) Dengan pemantauan yang lebih intensif, semua siswa sudah mau bekerja. 


\section{Edulnovasi: Journal of Basic Educational Studies \\ Volume 2 Nomor 1 (2022) 73-84 P-ISSN 2774-5058 E-ISSN 2775-7269 \\ DOI: 47467/eduinovasi.v2.i1.669}

\section{KESIMPULAN DAN SARAN}

\section{Kesimpulan}

Setelah pembelajaran dengan metode mind mapping dilaksanakan, peneliti mengambil kesimpulan sebagai berikut :

1. Metode mind mapping sangat diperlukan dalam pembelajaran Bahasa Indonesia khususnya pada kompetensi menulis karangan mengarang. Dengan membuat kerangka karangan dalam bentuk mind mapping yang dapat digambari dan diwarnai sesuka hati, dapat memotivasi siswa untuk mengekspresikan gagasannya melalui gambar yang beraneka ragam dan warna. Mind mapping juga dapat memunculkan ide, sehingga mempermudah siswa dalam menulis karangan /mengarang. Selain itu, mind mapping juga dapat memunculkan kreatifitas, yang terlihat dari hasil karya siswa SMK Negeri 2 Garut yang bagus-bagus dan menarik, diluar dugaan peneliti.

2. Implementasi metode mind mapping dalam penulisan karangan berbentuk deskripsi benar-benar menarik minat siswa. Hal ini dibuktikan dengan catatan hasil pengamatan kolaborator Lilis Sri Mulyani, S.Pd. , guru Bahasa Indonesia SMK Negeri 2 Garut, yang memberi catatan bahwa siswa sangat senang atau antusias dalam mengikuti pelajaran dengan metode mind mapping. Siswa juga sangat aktif dalam mengikuti pelajaran. Penampilan guru dan materi yang disajikan cukup baik, mengena dan mudah diterima siswa. Pada waktu ulangan, semua siswa terlihat asyik dalam mengerjakan tugas dan semua siswa dapat menyelesaikan tugas itu dengan baik.

3. Berdasarkan analisis hasil ulangan pada siklus pertama, dari 36 siswa, ada 32 siswa yang dapat mencapai nilai KKM. Berarti ketuntasan belajar klasikalnya $=(32: 36) \times 100 \%=89 \%$. Kelas dikatakan tuntas belajarnya apabila minimum 85\% siswanya dapat mencapai nilai KKM. Berarti kelas ini tuntas belajarnya. Sedang pada siklus kedua, dari 36 siswa, ada 34 siswa yang dapat memperoleh nilai lebih besar sama dengan nilai KKM. Ada kenaikan ketuntasan belajar sebanyak (2:36) x 100\% =6\%. Daya serap siklus pertama $=70,69 \%$, dan daya serap siklus kedua $=76 \%$.

\section{Saran}

Dari uraian dan kesimpulan di atas, peneliti menyarankan agar :

a. Guru Bahasa Indonnesia SMK supaya mencoba menggunakan metode mind mapping dalam pembelajaran kompetensi menulis karangan karangan. Selain menarik, karena dapat diberi gambar-gambar dan warna-warna sekehendak pembuatnya, juga dapat memunculkan kreatifitas siswa, memudahkan ulisan serta sesuai pendapat Buzan, dengan memanfaatkan gambar dan teks ketika kita mencatat atau mengeluarkan sesuatu yang ada di dalam diri, maka kita telah menggunakan dua belahan otak secara sinergis. Apalagi jika dalam peta pikiran itu, kemudian ditambahkan warna dan hal-hal yang memperkuat emosi ("Brain-Based Writing") 


\section{Edulnovasi: Journal of Basic Educational Studies Volume 2 Nomor 1 (2022) 73-84 P-ISSN 2774-5058 E-ISSN 2775-7269 DOI: 47467/eduinovasi.v2.i1.669}

2. Para guru atau pendidik pada umumnya, juga dapat menggunakan metode ini dalam segala kompetensi pembelajaran, karena metode ini cukup menarik, dapat memunculkan ide dan kreatifitas, memuat berbagai metode, dan mengajak orang untuk berpikir global. Yang juga berarti mengaktifkan otak kanan. Orang yang berpikir dengan kedua belah otaknya (otak kanan dan otak kiri) akan memperoleh hasil yang maksimal dalam tugas atau pekerjaannya.

\section{DAFTAR PUSTAKA}

Endang K Haris dkk. (1997). English Students Workshop - SLTP Class 1. Bandung : PT Remaja Rosda Karya.

http : // www.duniaguru.com/index.php Hernowo (2007) "Brain-Based Writing" http : //www.film pendek.org/Category-29/463-Peta-Pikiran-Mind-Mapping,html

http://en.wikipedia.org/wiki/Mind_map

Syamsi Kastam. (2006/2007). Penyusunan Proposal dan Laporan PTK. FBS UNY.

Depdikbud. 1999. Penelitian Tindakan (Action Research). Bahan Pelatihan Jakarta: Dikdasmen Depdikbud.

Capacchione. L. 1989. The Creative Journal For Children: A Guide for Parents, Teacher, and Counselors. Boston: Shambala.

Eanes, R. 1997. Content Area Literacy: Teaching Today's and Tomorrow. New York: Delmar Publisher.

Elliot, J. 1991. AN. Action Reseach for Educational Change. Buckingham: Open University Press.

Federikson, J. \& Collins, A. 2002. What is Authentic Assesment: Term and Condition of Use. Hougton Mifflin Company (online), (http://www/eduplace.com/rdg/res/litass/, diakses 28 Desember 2002).

Hammond, L.D. dan Snyde, J.D.2001. Authentic Assesment of Reaching Indonesia Context, U.S. Departemen Education (online), (http:www.Contextual.org/abs2.htm., diakses 29 Oktober 2001 oleh Darmono).

Laonhardt, M.2001. 99 Cara Menjadikan Anak Anda Bergairah Menulis. Terjemahan oleh Eva Y. Nukman. 2001. Bandung Kaifa. 


\section{Edulnovasi: Journal of Basic Educational Studies}

Volume 2 Nomor 1 (2022) 73-84 P-ISSN 2774-5058 E-ISSN 2775-7269

DOI: 47467/eduinovasi.v2.i1.669

Nurhadi \& Senduk, A.G. 2003. Pembelajaran Kontekstual dan Penerapannya dalam KBK. Malang: Penerbit Universitas Negeri Malang.

O'Malley, J.M. \& Piece, L.V. 1996. Authentic Assessment for Ennglish Language Learners: Practical Approaches For Teachers. Virginia: Addison-Wesley.

Puhl, C. 1997. Develop, Not Judge: Continuous Assesment in the ESL Classroom. English Teaching Forum, April 1997, pp 2-9.

Suparno, 2001. Pembelajaran Bahasa Indonesia dengan Pendekatan Kontekstual. Makalah disajikan pada Simposium di Wisma Jaya, Bogor. Direktorat SLTP, Dirjen Dikdasmen. November, 2001.

Tompkins, G.E \& Hoskisson, K. 1991. Language Arts : Content and Teaching Strategis. New York: Macmillan.

Tompskin, G.E. 1994. Teaching Writing Balancing Process and Product. New York: Macmillan. 